\title{
Antidiarrhoael and antimicrobial effects of ethanol root bark extract from Salacia lehmbachii
}

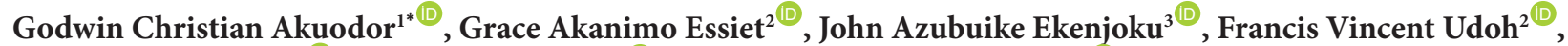 \\ Emeka Donald Ogiji $^{\circledR}$, Gideon Ama Ibiam ${ }^{5 \mathbb{D}}$, Friday Onyemazuwa Nnorom ${ }^{6}$ \\ ${ }^{1}$ Department of Pharmacology and Therapeutics, Faculty of Medicine, College Health Sciences, Nnamdi Azikiwe University, Nnewi Campus, Nigeria \\ ${ }^{2}$ Department of Pharmacology, College of Medical Sciences, University of Calabar, Calabar, Nigeria \\ ${ }^{3}$ Department of Pharmacology and Therapeutics, Abia State University, Uturu, Nigeria \\ ${ }^{4}$ Department of Pharmacology and Therapeutics, Faculty of Medicine, Ebonyi State University, Abakaliki, Nigeria \\ ${ }^{5}$ Department of Medical Laboratory Science, Faculty of Health Sciences and Technology, Ebonyi State University, Abakaliki, Nigeria \\ ${ }^{6}$ Department of Pharmaceutical Technology, Federal Polytechnic, Owerri, Nigeria
}

\section{A R T I C L E I N F O}

Article Type:

Original Article

\section{Article History:}

Received: 2 January 2020

Accepted: 19 June 2020

\section{Keywords:}

Salacia lehmbachii

Root bark

Antidiarrheal activity

Antimicrobial effect

Herbal medicine

\begin{abstract}
A B S T RAC T
Introduction: The roots of Salacia lehmbachii are used in Nigerian folklore medicine without scientific basis. The present study was aimed to investigate the antidiarrheal and antimicrobial activities of the ethanol extract of S. lehmbachii root bark.

Methods: The antidiarrheal activity was examined using castor oil induced diarrhoea method. The ethanol root bark extract effects on intestinal transit time and enteropooling were also evaluated in rats, while antimicrobial activity was conducted on selected microorganisms. The acute toxicity test and phytochemical screening of the extract were also carried out.

Results: The extract produced significant $(P<0.05)$ dose dependent protection on rats against castor oil induced diarrhoea. The extract inhibited intestinal transit time and caused significant dose related inhibition of castor oil induced enteropooling in rats, comparable to the standard drug, atropine $(P<0.05)$. The root bark extract significantly and dose dependently delayed the onset of castor oil induced diarrhoea, reduced the frequency of defecation and decreased the severity of diarrhoea in rats. S. lehmbachii ethanol root bark extract significantly and dose dependently decreased the volume of intestinal fluid accumulation in the castor oil induced enteropooling. The extract also significantly inhibited the growth of test organisms. The acute toxicity test produced no lethality in rats, whereas the phytochemical analysis revealed the presence of alkaloids, saponins, tannins, flavonoids, terpenoids, steroids, cardiac glycosides, resins and balsam.

Conclusion: The results of this study confirm the ethnomedicinal use of S. lehmbachii root bark as a valuable natural agent for the treatment of diarrhoea and microbial infections.
\end{abstract}

Implication for health policy/practice/research/medical education:

Salacia lehmbachii ethanol root bark extract significantly demonstrated high antidiarrheal, antimotility, antienteropooling as well as broad spectrum antibacterial activities. Thus, this plant can be considered as a candidate for bioassay guided and isolation of compounds which could possibly be developed into new lead structures for drug development programs against gastrointestinal disorders and infectious diseases.

Please cite this paper as: Akuodor GC, Essiet GA, Eenjoku JA, Udoh FV, Ogiji ED, Ibiam GA, et al. Antidiarrhoael and antimicrobial effects of ethanol root bark extract from Salacia lehmbachii. J Herbmed Pharmacol. 2021;10(2):188-193. doi: 10.34172/jhp.2021.20.

\section{Introduction}

Medicinal plants are used commonly by most people in rural areas in treatment of diseases traditionally and these are considered beneficial in healthcare. Medicinal plants are generally, considered to possess innumerable bioactive constituents which steadily increase their demand as an alternative to synthetic agents (1-3). More so, formulated products derived from these plants are safer with less harmful effect for human than the synthetic drugs (4). However, pharmacological evaluation of these agents is important for drug development. Thus, different plant parts have been on the focus for intense scientific

*Corresponding author: Godwin Christian Akuodor,

E-mail: goddyakuodor@yahoo.com,gc.akuodor@unizik.edu.ng 
researches, globally.

Salacia lehmbachii (Celasraceae) with many local names in Nigeria, Cameroon and Tanzania is a small tree with a height of about three meters, always green with firm and difficult to slice. The leaves are important in such conditions as pyrexia, diarrhea, motility and ulcers $(5,6)$. The extracts from the root have antioxidants (7), analgesic, anti-inflammatory (8), anti-cholinergic (9), anti-infertility (10) and anti-hemorrhoid effects (11). The present study investigated the antidiarrheal and antimicrobial activities of ethanol extract of S. lehmbachii root bark.

\section{Materials and Methods}

Plant collection

The roots of S. lehmbachii were collected from Akwa Ibom State, Nigeria. The roots were taxonomically identified in the Herbarium Unit of Department of Botany, University of Calabar, Calabar and voucher specimen deposited with number 688 .

\section{Preparation of root bark}

The root barks (S. lehmbachii) were washed, chopped into small pieces, air-dried at room temperature. The dried root barks were milled into fine powder with the aid of mortar and pestle. The powder was macerated in $2.5 \mathrm{~L}$ of ethanol at room temperature $\left(25 \pm 1^{\circ} \mathrm{C}\right)$ for 24 hours with occasional stirring and shaking. The filtrate concentrated on water bath at reduced temperature of $40^{\circ} \mathrm{C}$ to recover the extract, the gathered yield was $10.5 \% \mathrm{w} / \mathrm{w}$ light brown, powdery crude $S$. lehmbachii root bark ethanol extract. Aliquot portions residue of the extract weighed and dissolved in distilled water for use on each day of our experiments.

\section{Phytochemical screening}

The root bark extract was of S. lehmbachii tested for different secondary metabolites using standard methods $(12,13)$.

\section{Animals}

Healthy Wistar rats of both male and female weighing 180-220 g, were used for this study. All animals housed and maintained under laboratory conditions of temperature and humidity, with $12 \mathrm{~h}$ natural light/12 h dark cycles. They had free access to rat chow and clean water, except when fasting was required in the course of the study. Their cages were cleaned daily of wastes. The experimental procedures and protocols used in this study were approved by the Ethics Committee of the University of Calabar, Nigeria and conform to the guide to the care and use of laboratory animals in research and teaching (14).

\section{Test strains}

Pseudomonas aeruginosa, Salmonella typhi, Staphylococcus aureus, Shigella species and Escherichia coli, all clinical isolates obtained from the Microbiology Department, University College Hospital, Calabar, Nigeria were used in this study.

\section{Acute toxicity test}

Oral acute toxicity test was performed using the Organization of Economic Cooperation and Development (OECD) guideline for testing of chemicals 401 (15). Male and female rats weighing 180-220 g, were used for this study, and conducted in two phases. Three groups of 3 rats (all male separated from female) in each cage, were administered 100, 600 and $1000 \mathrm{mg} / \mathrm{kg}$ of the root bark extract orally. The rats were observed for signs of toxicity and mortality for 24 hours with special attention at first 4 hours. This was followed by administration of 2000, 3000 and $5000 \mathrm{mg} / \mathrm{kg}$ to the next three groups of 3 rats and observed for salivation, paw-licking, writhing (toxicity signs), change in body weight and mortality. The number of deaths was recorded in each group and the final $\mathrm{LD}_{50}$ values were calculated.

Evaluation of antidiarrheal activity of the root bark Castor oil induced diarrhea in rats

The procedure described previously $(16,17)$ with some modifications was used for the study. The animals were kept at $25^{\circ} \mathrm{C}$, fasted for 24 hours but had access to water prior to the experiment. Each rat was placed separately in a cage having blotting paper lined on the floor. The rats in the group 1 were orally treated with $20 \mathrm{~mL} / \mathrm{kg}$ distilled water. The rats in groups 2-4 were treated orally with 50,100 , and $200 \mathrm{mg} / \mathrm{kg}$ of the extract of S. lehmbachii ethanol root bark accordingly. The rats in group 5 were individually treated with $4 \mathrm{mg} / \mathrm{kg}$ of loperamide, a standard antidiarrheal agent. Thirty minutes after pretreatment of the animals, each rat was given $1 \mathrm{~mL}$ of castor oil in each of the five groups. The severity of diarrhea was monitored for 5 hours for diarrheal droppings. The number of diarrhea (drops) was recorded and compared with the controls. The percentage (\%) inhibition of diarrhea was calculated following the formula below (18):

$\%$ inhibition of defecation $=\frac{\text { Control mean-treated (test) mean }}{\text { Control mean }} \times 100$

\section{Castor oil-induced enteropooling test}

As described above, the rats used in this study were fasted for 24 hours (during which the animals had free access to clean water) and kept in five groups of 6 rats in a group. Each rat was separated and placed in a plastic cage lined with a transparent paper at the floor. The rats in group 1 were treated with $20 \mathrm{~mL} / \mathrm{kg}$ of distilled water each. The rats in groups 2-4 received S. lehmbachii ethanol root bark extract doses of 50,100 and $200 \mathrm{mg} / \mathrm{kg}$, respectively. Group 5 rats received $4 \mathrm{mg} / \mathrm{kg}$ of loperamide, followed by $1 \mathrm{~mL}$ of 
castor oil orally. Thirty minutes following administration of castor oil orally, each rat was sacrificed as previously described (19). The small intestine was excised, intestinal content expelled into a graduated measuring cylinder and its volume was determined using the formula. The intestinal content percentage inhibition was determined using the below formula (20):

$\%$ inhibition of intestinal fluid $=\frac{\text { Control-test extract }}{\text { Control }} \times 100$

\section{Intestinal transit test}

Adult rats of both sexes weighing 180-220 were allocated into five groups of 6 per group. Prior to the experiments, the rats were fasted for 24 hours (during this time they were given free access to clean water ad libitum). Group 1 rats were treated with $20 \mathrm{~mL} / \mathrm{kg}$ of distilled water. Group 2-4 rats received doses of 50, 100 and $200 \mathrm{mg} / \mathrm{kg}$ root bark extract. Group 5 rats received $5 \mathrm{mg} / \mathrm{kg}$ atropine sulphate each. Thirty minutes later, the animals were given $1 \mathrm{~mL}$ of charcoal meal (10\% charcoal suspension in $5 \%$ tragacanth) each, orally. All rats were sacrificed after half an hour of charcoal meal. The small intestine of each rat was dissected out from the pylorus to the caecum, and the total distance traversed by the charcoal plug along the small intestine, was determined in both the control and treated groups (expressed as a percentage) (21).

$\%$ inhibition $=$

Mean length of intestine - mean distance traveled by meal Mean length of intestine

Antimicrobial activity of the extract

The clinical isolates of 5 bacteria species, consisted of Pseudomonas aeruginosa, Salmonella typhi, Staphylococcus aureus, Shigella species and Escherichia coli, were sourced from Microbiology Department of University College Hospital, Calabar, Nigeria. Each organism maintained on nutrient agar slants was recovered by sub-culturing on nutrient broth after 24 hours. Before use, the bacterial culture was diluted each to 1:100 in fresh sterile nutrient broth (22). The organisms to be tested were streaked on sterile nutrient agar plates, incubated at $37^{\circ} \mathrm{C}$, and then examined after 24 hours. Total growth suppression by specific concentration of the test extract was needed to be made active. The ethanol root bark $S$. lehmbachii extract was tested at final doses of 6.25, 12.5, 25, 50, 100 and 125 $\mu \mathrm{g} / \mathrm{mL}$. Plates in blank containing nutrient agar only and other sets having nutrient agar with ethanol were served as controls, while gentamicin $(10 \mu \mathrm{g} / \mathrm{mL})$ was used as standard drug. The treatment (each) was performed in triplicate, while inhibition of complete bacterial growth was required to declare the extract bioactive.

Determination of minimum inhibitory concentration The minimum inhibitory concentration (MIC) of the extract was assayed through micro dilution method (23). Ethanol root bark extract of S. lehmbachii which inhibits growth of one or more microorganisms was examined for MIC. Serial dilutions of the extract were prepared to the concentrations of $6.25,12.5,25,50,100$ and $125 \mu \mathrm{g} /$ $\mathrm{mL}$. The wells for the test were inoculated with $0.1 \mathrm{~mL}$ aliquot containing the test organisms $\left(1 \times 10^{6} \mathrm{cfu} / \mathrm{mL}\right)$ and serial dilution of the root bark extract containing $50 \mu \mathrm{L}$ each. Thereafter, micro plate was incubated at $37^{\circ} \mathrm{C}$ for 24 hours and dilutions of the extract corresponding to each test organism showing no visible growth was considered as the MIC.

\section{Statistical analysis}

Data were expressed as the mean \pm SEM of six determinations. The significance of difference between means was determined using one way analysis of variance (ANOVA) followed by Dunnett's post hoc test (24). Statistical significance was established at $P<0.05$.

\section{Results}

Phytochemical screening

It is important to know the chemical nature of plant products when their pharmacological responses are screened (12). Phytochemical evaluation of S. lehmbachii root bark extract showed the presence of the following secondary metabolites; alkaloids, saponins, tannins, flavonoids, terpenoids, steroids, cardiac glycosides, resins and balsam.

\section{Acute toxicity test}

There was no observed behavioral changes, mortality or signs of toxicity in 48-day period following observation in rats receiving $5000 \mathrm{mg} / \mathrm{kg}$ of the extract root bark. Hence, the median lethal dose (LD50) was found to be greater than $5000 \mathrm{mg} / \mathrm{kg}$.

Effect of castor oil induced diarrhea test in rats

Pretreatment of the rats with S. lehmbachii ethanol root bark extract (50 mg/kg, $100 \mathrm{mg} / \mathrm{kg}$ and $200 \mathrm{mg} / \mathrm{kg}$, orally) dose dependently and significantly $(P<0.05-0.01)$ delayed the onset of diarrhea, lowered rate of dropping and reduced the severity of diarrhea in rats. The standard drug, loperamide ( $4 \mathrm{mg} / \mathrm{kg}$, orally), showed a marked and significant $(P<0.01)$ antidiarrheal effect than the highest dose of the extract $(400 \mathrm{mg} / \mathrm{kg})$ used (Table 1).

\section{Effect of intestinal transit test in rats}

The effect of S. lehmbachii root bark extract on the intestinal transit is shown on Table 2. The root bark (50 mg/kg, $100 \mathrm{mg} / \mathrm{kg}$ and $200 \mathrm{mg} / \mathrm{kg}$, orally) dose dependently and significantly $(P<0.05-0.01)$ decreased the propulsive movement and transit charcoal meal. However, the standard drug, atropine sulphate $(5 \mathrm{mg} / \mathrm{kg})$ demonstrated marked and significant $(P<0.01)$ inhibition 
Table 1. Effects of Salacia lehmbachii ethanol root bark extract of castor oil induced diarrhea in rats

\begin{tabular}{lccc}
\hline Drug & Dose $(\mathbf{m g} / \mathbf{k g})$ & $\begin{array}{c}\text { Mean diarrhea } \\
\text { frequency (4 h) }\end{array}$ & \% Protected \\
\hline Control & $0.2 \mathrm{~mL}$ & $12.17 \pm 0.87$ & 0.0 \\
S. lehmbachii & 50 & $4.33 \pm 0.67$ & $64^{\mathrm{a}}$ \\
S. lehmbachii & 100 & $2.80 \pm 0.65$ & $77^{\mathrm{b}}$ \\
S. lehmbachii & 200 & $1.33 \pm 0.56$ & $89^{\mathrm{b}}$ \\
Loperamide & 4 & $1.00 \pm 0.52$ & $92^{\mathrm{b}}$ \\
\hline
\end{tabular}

One-way ANOVA + Dunnett's post hoc test $(n=6) .{ }^{a} P<0.05,{ }^{b} P<0.01$ compared to control.

in intestinal motility than the highest dose $(400 \mathrm{mg} / \mathrm{kg})$ of the root bark extract used in the experiment.

Effect of castor oil induced enteropooling test in rats Pretreatment of the test groups of rats $(50 \mathrm{mg} / \mathrm{kg}$, $100 \mathrm{mg} / \mathrm{kg}$ and $200 \mathrm{mg} / \mathrm{kg}$, orally) of the extract dose dependently and significantly $(P<0.05-0.01)$ inhibited castor oil induced fluid accumulation. The standard antidiarrhea drug, (loperamide $4 \mathrm{mg} / \mathrm{kg}$ ) showed more marked $(P<0.01)$ inhibitory effect on castor oil induced fluid accumulation than the highest dose of the extract (400 mg/kg) employed (Table 3). The intestinal fluids of the rats pretreated with the ethanol root bark extract and loperamide were more viscous than control rats treated with distilled water.

\section{Antibacterial activity}

The antimicrobial activity of S. lehmbachii root bark extract is presented on Table 4 . The extract showed activity against all the organisms tested. Gentamycin tested at 10 $\mu \mathrm{g} / \mathrm{mL}$, inhibited four of the organisms, while Shigella spp was moderately inhibited.

Minimum inhibitory concentration

The MIC of ethanol root bark extract of S. lehmbachii against the organisms were obtained as follows: $S$. aureus (26), P. aeruginosa (45), S. typhi (30), Shigella spp (30) and E. coli (55).

\section{Discussion}

Diarrhea, which due to altered motility and accumulation of fluid around the intestinal tract. Most agents with antidiarrheal property show activity by lowering
Table 3. Effect of Salacia lehmbachii ethanol root bark extract on castor oil induced enteropooling in rats

\begin{tabular}{lccc}
\hline Drug & $\begin{array}{c}\text { Dose } \\
(\mathrm{mg} / \mathrm{kg})\end{array}$ & $\begin{array}{c}\text { Intestinal fluid } \\
(\mathrm{mL})\end{array}$ & $\begin{array}{c}\text { Inhibition of intestinal } \\
\text { fluid volume (\%) }\end{array}$ \\
\hline Control & $0.2 \mathrm{~mL}$ & $2.68 \pm 0.08$ & 0.0 \\
S. lehmbachii & 50 & $1.05 \pm 0.03$ & $61^{\mathrm{a}}$ \\
S. lehmbachii & 100 & $0.87 \pm 0.18$ & $68^{\mathrm{a}}$ \\
S. lehmbachii & 200 & $0.42 \pm 0.18$ & $84^{\mathrm{b}}$ \\
Loperamide & 4 & $0.37 \pm 0.12$ & $86^{\mathrm{b}}$ \\
\hline
\end{tabular}

One-way ANOVA + Dunnett's post hoc test $(n=6) .{ }^{a} P<0.05,{ }^{b} P<0.01$ compared to control.

Table 4. Zone of inhibition ( $\mathrm{mm}$ ) of organisms by ethanol root bark extract of Salacia lehmbachii and gentamicin

\begin{tabular}{lcc}
\hline \multirow{2}{*}{ Organisms } & \multicolumn{2}{c}{ Zone of inhibition $(\mathbf{m m})$} \\
\cline { 2 - 3 } & S. lehmbachii extract & Gentamicin \\
\hline S. aureus & 20 & 24 \\
P. aeruginosa & 18 & 20 \\
S. typhi & 19 & 22 \\
Shigella spp & 15 & 19 \\
E. coli & 12 & 17 \\
\hline
\end{tabular}

gastrointestinal motility or its secretions. Ricinoleic acid, a castor oil metabolite could bring about diarrhea (25, 26) which might increase motility tone in small intestine and alter electrolyte permeability in the membrane of intestinal mucosa $(27,28)$. However, Ricinoleate stimulates endogenous secretion of the prostaglandin (29). Prostaglandins E series are reported as good agents for diarrhea in both humans and animals (30). Moreover, disruption of prostaglandin biosynthesis may shorten castor oil induced diarrhea (31). The root bark extract of $S$. lehmbachii exhibited significant antidiarrheal activity. Tannins, flavonoids, saponins and steroids as plants secondary metabolites have shown antidiarrheal properties (32-34). The root bark extract exhibited significant dose dependent reductions in castor oil induced diarrhea, which is a clear evidence of its antidiarrheal potential when compared with the standard antidiarrheal drug, loperamide at $10 \mathrm{mg} / \mathrm{kg}$. Apart from regulating gastrointestinal tract, loperamide also reduce intestinal transit time, the rate of colon out-flow and colonic motility (35).

Table 2. Effect of Salacia lehmbachii ethanol root bark extract on intestinal transit in rats

\begin{tabular}{lcccc}
\hline Drug & Dose $(\mathbf{m g} / \mathbf{k g})$ & Intestinal lenght $(\mathbf{c m})$ & Distance travelled by charcoal meal $(\mathbf{c m})$ & Inhibition of transit (\%) \\
\hline Control & $0.2 \mathrm{~mL}$ & $88.83 \pm 1.81$ & $86.17 \pm 2.07$ & $27.17 \pm 2.07$ \\
S. lehmbachii & 50 & $86.50 \pm 2.46$ & $21.17 \pm 2.75$ \\
S. lehmbachii & 100 & $86.00 \pm 1.88$ & $13.50 \pm 1.35$ \\
S. lehmbachii & 200 & $82.50 \pm 1.84$ & $11.83 \pm 1.05$ & $75^{\mathrm{b}}$ \\
Atropine & 5 & $84.50 \pm 1.61$ & $84^{\mathrm{b}}$ \\
\hline
\end{tabular}

One-way ANOVA + Dunnett's post hoc test $(n=6) .{ }^{\text {a }} P<0.05,{ }^{b} P<0.01$ compared to control. 
The graded doses of the root bark extract significantly decreased intestinal transit time by a reduction in distance travelled charcoal meal. Atropine at $5 \mathrm{mg} / \mathrm{kg}$, decreased propulsive movement in charcoal meal test following its anticholinergic effect (35). In castor oil induced enteropooling study, the root bark extract demonstrated significant reductions of water contents at different doses, as well as frequency of defecation and intestinal fluid accumulation. The remarkable inhibition of castor oil induced enteropooling in rats shows that the extract may produce relief in diarrhea through its spasmolytic and antienteropooling effects.

The extract of S. lehmbachii (root bark) possessed broad spectrum of antimicrobial activity against S. aureus, shigella spp, P. aeruginosa, S. typhi and E. coli. The results suggest that the plant extract could be used in the treatment of dysentery and diarrhea (36). Increased inhibition was found against $S$. aureus and $S$. typhi. The findings have shown that the extract could possess antagonizing qualities capable of preventing microbial survival.

Plants synthesize phytoconstituents which have health stimulating properties and the constituents of these plants possess health stimulating effect, whose importance increases their intake in our diet (37). Moreso, investigation of their initial secondary metabolites might help in detecting bioactive components which could assist in drug discovery and development (12). The oral acute toxicity test of the root bark extract could not be determined, as neither toxicity signs nor mortality was observed up to $5000 \mathrm{mg} / \mathrm{kg}$, suggesting the extract to be safe with a wide therapeutic range.

\section{Conclusion}

The discussed results in this experimental study indicates that S. lehmbachii root bark extract possesses antidiarrheal and antimicrobial activities. The findings therefore validate the use of Salacia lehmbachii root bark as antidiarrheal and antimicrobial agents in traditional medicine in Nigeria. However, further studies are now under way to isolate, characterize and determine the structure of the plant active constituents.

\section{Acknowledgements}

The authors are grateful to Mr. Marcus Inyang and Etim Ifang for their technical assistance.

\section{Authors' contributions}

GCA conceived the research idea and designed the work, GAE and JAE wrote the first draft of the manuscript, EDO and FON carried out the literature search, GAI carried out the statistical analysis, while FVU supervised the study. All authors read and approved the final manuscript.

\section{Conflict of interests}

No conflict of interest is associated with this study.

\section{Ethical considerations}

The protocol for this study was confirmed by Animal Research Ethical Committee, University of Calabar (ERN/025PA30617) and the authors of this manuscript observed ethical issues. Animals were handled according to the International Guidelines for Care and Handling of Experimental Animals.

\section{Funding/Support}

This research was financially supported by the authors.

\section{References}

1. Rakh MS, Chaudhari SR. Evaluation of CNS depressant activity of Momordica dioica Roxb willd fruit pulp. Int J Pharm Pharm Sci. 2010;2(4):124-6.

2. Gill NS, Bajwa J, Dhiman K, Sharma P, Sood S, Sharma PD, et al. Evaluation of therapeutic potential of traditionally consumed Cucumis melo seeds. Asian J Plant Sci. 2011;10(1):86-91. doi: 10.3923/ajps.2011.86.91.

3. Huang C, Zhou T, Chen Y, Zhang S, Chen G. Epicatechin Regulation of Hydroxysteroid Sulfotransferase STa (rSULT2A1) Expression in Female Rat Steroidogenic Tissues. J Pharmacol Toxicol. 2011;6(4):349-60. doi: 10.3923/jpt.2011.349.360.

4. Alam MB, Hossain MS, Chowdhury NS, Mazumder MEH, Haque ME, Islam A. In vitro and in vivo antioxidant and toxicity evaluation of different fractions of Oxalis corniculata Linn. J Pharmacol Toxicol. 2011;6(4):337-48. doi: $\quad 10.3923 /$ jpt.2011.337.348.

5. Essien AD, Akuodor GC, Essien EA, Asika EC, Chilaka KC, Nwadum SK. Evaluation of antipyretic potential of the ethanolic leaf extract of Salacia lehmbachii Loes. Asian J Med Sci. 2015;7(2):22-5.

6. Essien AD, Takem LP, Anele EI. In vitro cholinergic and acute toxicity evaluations of Salacia lehmbachii. Int J Pharm Pharm Res. 2016;5(1):200-7.

7. Akuodor GC, Essiet GA, Essien AD, Udoh FV, Ogiji DE, Nwadum SK, et al. In vitro antioxidant activity of Salacia lehmbachii ethanol root bark extract. Eur J Med Plants. 2017;18(4):1-6. doi: 10.9734/ejmp/2017/32014.

8. Takem LP, Lawal BAS, Udia PM. Analgesic and acute antiinflammatory activities of aqueous root extract of Salacia lehmbachii. Br J Pharm Res. 2014;4(18):2172-81. doi: 10.9734/bjpr/2014/9250.

9. Essien AD, Essiet GA, Akuodor GC, Aja DOJ, Thomas EE. Studies on gastrointestinal properties of ethanolic leaf extract of Salacia lehmbachii in Wistar rats. Afr J Pharm Pharmacol. 2016;10(20):451-7. doi: 10.5897/ajpp2016.4536.

10. Essiet GA, Essien AD, Udoh FV, Essiet A. Anti-fertility effects of ethanol extract of Salacia lehmbachii root bark in Albino rats. J Adv Med Pharm Sci. 2016;8(4):1-8. doi: 10.9734/jamps/2016/26576.

11. Sofowora A. Medicinal Plants and Traditional Medicine in Africa. Ibadan: Spectrum Books; 1993. p. 200.

12. Aziz MA. Qualitative phytochemical screening and evaluation of anti-inflammatory, analgesic and antipyretic activities of Microcos paniculata barks and fruits. J Integr Med. 2015;13(3):173-84. doi: 10.1016/s20954964(15)60179-0. 
13. Billmary C, Janne R, Luccro M, Maria C. Preliminary phytochemical screening of Pimenta racemosa var. racemosa (Myrtaceae) from Táchira-Venezuala. Pharmacologyonline. 2015;1:121-5.

14. National Institutes of Health (NIH). Guide for the Care and Use of Laboratory Animals. 8th ed. Bethesda, MD: NIH; 2011. p. 82-3.

15. OECD. OECD Guideline for Testing of Chemicals (TG 401). Acute Oral Toxicity- Fixed Dose Procedure. OECD/ OCDE; 2011.

16. Mbagwu HO, Adeyemi OO. Anti-diarrhoeal activity of the aqueous extract of Mezoneuron benthamianum Baill (Caesalpiniaceae). J Ethnopharmacol. 2008;116(1):16-20. doi: $10.1016 /$ j.jep.2007.10.037.

17. Suleiman MM, Dzenda T, Sani CA. Antidiarrhoeal activity of the methanol stem-bark extract of Annona senegalensis Pers. (Annonaceae). J Ethnopharmacol. 2008;116(1):12530. doi: 10.1016/j.jep.2007.11.007.

18. Awe EO, Kolawole SO, Wakeel KO, Abiodun OO. Antidiarrheal activity of Pyrenacantha staudtii Engl. (Icacinaceae) aqueous leaf extract in rodents. J Ethnopharmacol. 2011;137(1):148-53. doi: 10.1016/j. jep.2011.04.068.

19. Daswani PG, Brijesh S, Tatali P, Antia NH, Birdi TJ. Antidiarrhoeal activity of Zingiber officinale (Rosc.). Curr Sci. 2010;98(Suppl 2):222-9.

20. Bakare RI, Magbagbeola OA, Akinwande AI, Okunowo OW, Green M. Antidiarrhoeal activity of aqueous leaf extract of Momordica charantia in rats. J Pharmacogn Phytother. 2011;3(1):1-7.

21. Bairagi SM, Aher AA, Nema N, Pathan IB. Evaluation of antidiarrhoeal activity of the leaves extract of Ficus microcarpa L. (Moraceae). Marmara Pharm J. 2014;3(18):135-8. doi: 10.12991/mpj.2014187240.

22. Afolayan AJ, Meyer JJ. The antimicrobial activity of 3,5,7-trihydroxyflavone isolated from the shoots of Helichrysum aureonitens. J Ethnopharmacol. 1997;57(3):177-81. doi: 10.1016/s0378-8741(97)00065-2.

23. Umer S, Tekewe A, Kebede N. Antidiarrhoeal and antimicrobial activity of Calpurnia aurea leaf extract. BMC Complement Altern Med. 2013;13:21. doi: 10.1186/14726882-13-21

24. Buncher CR, Tsay JY. Statistics in the Pharmaceutical Industry. 2nd ed. New York: Marcel Dekker; 1993. p. 397433.

25. Chaulya NC, Halader PK, Mukherjee A. Antidiarrhoeal activity of methanol extract of the rhizomes of Cyperus tegetum Roxb. Int J Pharm Pharm Sci. 2011;3(1):133-5.

26. Essiet GA, Akuodor GC, Aja DO, Megwas AU, Ekenjoku JA, Nworie EM. Antidiarrhoeal and antioxidant properties of ethanol leaf extract of Pseudocedrela kotschyi. J Appl Pharm Sci. 2016;6(3):107-10. doi: 10.7324/japs.2016.60318.
27. Balogun SO, Tanayen JK, Ajayi AM, Ibrahim A, Oloro OJ, Goji ADT, et al. Preliminary evaluation of anti-diarrheal, ulcer-protective and acute toxicity of aqueous ethanolic stem bark extract of Ficus trichopoda in experimental rodents. Asian J Med Sci. 2011;3(1):37-42.

28. Akuodor GC, Muazzam I, Usman-Idris M, Megwas AU, Akpan JL, Chilaka KC, et al. Evaluation of the antidiarrheal activity of methanol leaf extract of Bombax buonopozense in rats. Ibnosina J Med Biomed Sci. 2011;3(1):15-20. doi: 10.4103/1947-489x.210845.

29. Rahman MK, Chowdhury MA, Islam MT, Chowdhury MA, Uddin ME, Sumi CD. Evaluation of antidiarrheal activity of methanolic extract of Maranta arundinacea Linn. leaves. Adv Pharmacol Sci. 2015;2015:257057. doi: $10.1155 / 2015 / 257057$.

30. Rahman MK, Barua S, Islam MF, Islam MR, Sayeed MA Parvin MS, et al. Studies on the anti-diarrheal properties of leaf extract of Desmodium puchellum. Asian Pac J Trop Biomed. 2013;3(8):639-43. doi: 10.1016/s22211691(13)60129-x.

31. Awouters F, Niemegeers CJ, Lenaerts FM, Janssen PA. Delay of castor oil diarrhoea in rats: a new way to evaluate inhibitors of prostaglandin biosynthesis. J Pharm Pharmacol. 1978;30(1):41-5. doi: 10.1111/j.20427158.1978.tb13150.x.

32. Akuodor GC, Mbah CC, Essien AD, Akpan JL, Ezeokpo BC, Iwuanyanwu TC, et al. Ulcer-protective and antidiarrhoeal effects of the aqueous stem bark extract of Bridelia ferruginea in rodents. Pharmacologia. 2012;3(11):591-7. doi: $\quad 10.5567 /$ pharmacologia.2012.591.597.

33. Ezenwali MO, Njoku OU, Okoli CO. Studies on the antidiarrheal properties of seed extract of Monodora tenuifolia. Int J Appl Res Nat Prod. 2010;2(4):20-6.

34. Saralaya MG, Patel P, Patel M, Roy SP, Patel AN. Antidiarrheal activity of methanolic extract of Moringa oleifera Lam roots in experimental animal models. Int J Pharm Res. 2010;2:35-9. doi: 10.31838/ijpr/2018.10.03.100.

35. Brown JH and Taylor P. Muscarinic receptor agonists and antagonist. In: Hardman JG, Limbird LE, eds. Goodman and Gilman's The Pharmacological Basis of Therapeutics. 9th ed. New York: McGraw Hill; 1996.

36. Akuodor GC, Nwobodo NN, Megwas AU, Akpan JL, Nwachukwu DC, Asika EC, et al. Antidiarrheal and antimicrobial activities of the ethanol extract from the Icacina senegalensis root bark. J Basic Clin Physiol Pharmacol. 2018;29(2):211-6. doi: 10.1515/jbcpp-2016-0174.

37. Singh S. Enhancing phytochemical levels, enzymatic and antioxidant activity of spinach leaves by chitosan treatment and an insight into the metabolic pathway using DART-MS technique. Food Chem. 2016;199:176-84. doi: 10.1016/j. foodchem.2015.11.127. 